\title{
A fresh start in ambersnail (Gastropoda: Succineidae) taxonomy: finding a foothold using a widespread species of Oxyloma
}

\author{
Kathryn E. PEREZ ${ }^{1, *}$, Marco A. MARTINEZ CRUZ ${ }^{2}$, \\ Brent W. STEURY ${ }^{3} \&$ Gary M. BARKER ${ }^{4}$ \\ 1,2Biology Department, University of Texas Rio Grande Valley, \\ 1201 W. University Dr., Edinburg, TX, 78504, USA. \\ ${ }^{2}$ McGovern Medical School, The University of Texas Health Science Center, \\ 6431 Fannin St, Houston, TX, 77030, USA. \\ ${ }^{3}$ National Park Service, George Washington Memorial Parkway Headquarters, \\ 700 George Washington Memorial Parkway, McLean, VA 22101, USA. \\ ${ }^{4}$ Landcare Research, 54 Gerald Street, Lincoln 7608, Lincoln, New Zealand. \\ *Corresponding author: perezke@gmail.com \\ 2Email: martinezcruzmarco.a@gmail.com \\ 32Email: Brent Steury@nps.gov \\ [4Email: BarkerG@landcareresearch.co.nz

\footnotetext{
${ }^{1}$ urn:1sid:zoobank.org:author:19C6899F-D78F-418F-9725-A5BDA3A42EB9

${ }^{3}$ urn:lsid:zoobank.org:author:610250FC-1EE2-4957-B16E-5EF318D9A4D1
} \\ ${ }^{2}$ urn:1sid:zoobank.org:author:ACAD1CFB-FE89-4628-AF52-48163BBBC6E0 \\ ${ }^{4}$ urn:lsid:zoobank.org:author:17EE4345-3337-4A81-8D11-90BD9C60732A
}

\begin{abstract}
The ambersnails (Succineidae), found nearly worldwide, are considered a very challenging group to classify and identify with even genus-level identifications requiring dissection. In this study, we use mitochondrial and nuclear DNA markers, shell morphometrics, and anatomical dissection to examine fresh material collected from the type localities of two nominal species in Oxyloma (Neoxyloma). We conclude from these evidence that Oxyloma salleanum (L. Pfeiffer, 1850) and Oxyloma effusum (L. Pfeiffer, 1853) are conspecific, and accordingly reduce $O$. effusum to the status of junior synonymy. We present a redescription of $O$. salleanum.
\end{abstract}

Keywords. Mollusc phylogenetics, integrative taxonomy, COI, LSU, land snail anatomy.

Perez K.E., Martinez Cruz M.A., Steury B.W. \& Barker G.M. 2021. A fresh start in ambersnail (Gastropoda: Succineidae) taxonomy: finding a foothold using a widespread species of Oxyloma. European Journal of Taxonomy 757: 102-126. https://doi.org/10.5852/ejt.2021.757.1419

\section{Introduction}

Among land snails, identifications are often based on features of the shell. However, the ambersnails (Succineidae), found nearly worldwide, are considered a very challenging group to identify, with even 
genus-level identifications requiring dissection of soft tissues (Pilsbry 1948; Nekola 2014). The shells of this group are for the most part highly conservative, with a succiniform shape characterized as elongate (higher than wide), with a brief spire atop a very expanded body whorl terminating in a large aperture (greater than $50 \%$ of shell height). Generally, the shell is thin and lacking significant surface sculpture (Patterson 1972). Within the succiniform shape, subtle infraspecific variability commonly occurs in rate of body whorl expansion; degree of curvature of the body whorl lateral periphery and the basal periphery of the aperture; and height and breadth of the aperture relative to shell height. Shell shape variations within the family are largely associated with shell reduction where, in the initial stages of shell retrogression the animal can no longer retract entirely within the shell, and further retrogressive evolution leads to shell internalization (Patterson 1973).

Two recent attempts to clarify species boundaries using integrative taxonomic methods in ambersnails found no relationship between species boundaries delimited with DNA when compared with shell and anatomical characteristics (Culver et al. 2013; Vidigal et al. 2018) and have found fewer species supported by integrative taxonomy than the historical taxonomy. These techniques have yet to be applied widely in systematic studies of ambersnails, including those of Eastern North America. In this study we attempt to gain a foothold into the taxonomy of this challenging group.

For our foothold we selected a previously recognized taxonomic unit within North American Succineidae Beck, 1837, namely the Oxyloma effusum Group. Pilsbry (1948) distinguished this group of American taxa from Oxyloma Westerlund, 1885 s. str. (typified by the European Succinea dunkeri L. Pfeiffer, 1865 by erecting the Section Neoxyloma Pilsbry, 1948, with Succinea effusa L. Pfeiffer, 1853 as the type). Neoxyloma includes all North American species assigned to Oxyloma except for the subarctic Oxyloma groenlandicum (Möller, 1842) that extends to Greenland, western Canada and Alaska. Oxyloma is well defined morphologically, with the shell possessing a short spire and the body whorl with elongate aperture occupying a high proportion of the shell height; and the penis, within a sheath, bearing an apical appendix (Pilsbry 1948; Patterson 1972, 1973). A straight or moderately sinuous epiphallus proximal to a bent or coiled upper part of the penis was used by Pilsbry (1948) as the sole anatomical character to separate Neoxyloma from Oxyloma s. str., where a coiled, convoluted epiphallus is proximal to a straight penis. In reference to North American members of the genus, Pilsbry (1948: 775) remarked "Oxyloma is by far our most difficult genus of Succineidae. Much further study of the shells, genitalia and teeth must be carried on before satisfactory specific characters and limits are attained. These, together with the synonymy, are at present in a makeshift stage, there being some well-defined species, but also many named forms of uncertain status." While there has been much progress since, particularly through anatomical studies of Pilsbry (1948), Miles (1958), Franzen (1963, 1964, 1971, 1983, 1985), Patterson (1972, 1973), Wu (1993), and Culver et al. (2013), our knowledge of the anatomical variation in North American Oxyloma remains fragmentary and rudimentary.

In ambersnails, much of the circumscription of species and assignment to genus-group relies primarily on characteristics of the genitalia (Patterson 1972, 1973). However, recent workers have found that these features may not contribute to accurate species delineation in other gastropod groups (e.g., Roth et al. 2013). In addition, previous workers in Northern American Oxyloma have demonstrated substantial variation in the genitalia anatomy within nominal species-level taxa, including size and shape of the penial appendix, and straight vs coiled epiphallus and penis (e.g., Örstan 2010; Culver et al. 2013). It remains unclear if components of this variation relate to changes during ontogeny, parasitic infestation, and to fixation artifacts in preserved specimen material. At the more fundamental level, it is uncertain if genitalia anatomy as one of the classically important taxonomic features in land snails (alongside shells), provides taxonomically useful characters within succineid genera such as Oxyloma. 
Our studies on Oxyloma (Neoxyloma) are on-going. Of 15 nominal species currently recognized in Oxyloma (Neoxyloma), we focus this report on two nominal species believed to be primarily found in the Eastern and Southeastern United States, O. effusum (L. Pfeiffer, 1853) and O. salleanum (L. Pfeiffer, 1850). Using an integrative approach, based on DNA sequences, shell morphology, and both external and internal soft tissue morphology of individuals from type localities and agreeing conchologically with the respective type material, we investigated the systematics and taxonomic status of these two nominal members of the Oxyloma (Neoxyloma).

\section{Material and methods}

We focused collections on 'topotypes' (i.e., specimens collected from the type locality) that match the type material in shell morphology (anatomy was not presented in the original descriptions). The type localities as defined in the original works (Pfeiffer 1850, 1853), were geographically vague (e.g., O. effusum "Habitat in Florida orientali"). Accordingly, we delimited the respective type localities by examination of the original labels associated with type material (syntypes in Natural History Museum UK, henceforth NHMUK, formerly British Museum of Natural History), or secondarily by geographic information from the original authors' field notes and other collections made from wetlands during the expedition in which material of Oxyloma were acquired. These topotype material were supplemented in the present study by collections made from a range of other localities across eastern North America and sequences on GenBank (Fig. 1, Supp. file 1). Living individuals were collected from wetlands by hand, from canoe, usually on wet banks, and on emergent cattails and water hyacinth. After collection specimens were preserved in $95 \%$ ethanol that was refreshed once. They were tentatively identified conchologically by comparison to species descriptions and type material, including by reference to the characteristics of shell morphology that were indicated as defining each taxon (Pilsbry 1948).

\section{Sequence data}

Collected specimens were washed to remove potential external contaminants using $90 \%$ ethanol. A small ( $100 \mathrm{mg}$ ) piece of foot tissue was excised, and DNA extracted using the CTAB protocol (SaghaiMaroof et al. 1984). The resuspended DNA was then purified using the IBI Scientific Gel/PCR DNA fragment extraction kit (IB47030), following instructions provided by the manufacturer. This secondary extraction step enhances polymerase chain reaction (PCR) success in snails with high mucous production (pers. obs.), which was observed in our material.

DNA resuspended in Tris-EDTA-RNase A (10 mM: $1 \mathrm{mM}: 10 \mathrm{mg} / \mathrm{mL})$ was used as template for PCR using $\sim 1 \mathrm{ng}$ of template, $0.05 \mathrm{U}$ New England Biolabs Taq, $0.2 \mu \mathrm{M}$ of each primer, $0.2 \mathrm{mM}$ dNTPs, and $1 \mathrm{X}$ Taq reaction buffer. Mitochondrial COI, cytochrome oxidase subunit-I (Folmer et al. 1994) was amplified and sequenced using primers LCO1490 and HCO2198. The LSU region of the ribosomal (R) RNA genecluster (5.8-ITS-28S) was amplified and sequenced using the LSU1 and LSU3 primers (Wade et al. 2001). This region includes a small section of 5.8S, the entire internal transcribed spacer 2 (ITS-2), and part of the large 28S subunit. Amplification of these genes was conducted with the following temperature conditions: COI: $92^{\circ} \mathrm{C}, 2 \mathrm{~min}\left(30\right.$ cycles: $\left.92^{\circ} \mathrm{C}, 40 \mathrm{~s} ; 41.9^{\circ} \mathrm{C}, 40 \mathrm{~s} ; 72^{\circ} \mathrm{C}, 1: 30 \mathrm{~min}\right) 72^{\circ} \mathrm{C}, 5 \mathrm{~min} ; 8^{\circ} \mathrm{C}, \infty$; LSU: $94^{\circ} \mathrm{C}$, $30 \mathrm{~s}\left(35\right.$ cycles: $\left.94^{\circ} \mathrm{C}, 10 \mathrm{~s} ; 51.2^{\circ} \mathrm{C}, 30 \mathrm{~s} ; 72^{\circ} \mathrm{C}, 1: 30 \mathrm{~min}\right) 72^{\circ} \mathrm{C}, 10 \mathrm{~min} ; 12^{\circ} \mathrm{C}, \infty$. LSU amplification resulted in multiple fragments, so these samples were excised and extracted using IBI scientific Gel/PCR DNA fragment extraction kit (IB47030) prior to sequencing. Sanger sequencing of amplified fragments was carried out by Eurofins Genomics. Geneious ver. 10.2.3 (Kearse et al. 2012) was used for contig production, cleaning, and production of consensus sequences.

\section{Phylogenetic analysis}

Sequences generated (GenBank MK575889-MK576001 and MK 760578-MK 760659) for each gene fragment were, along with available sequences from GenBank (Supp. file 1) aligned using MUSCLE 
(Edgar 2004) as implemented at EMBL.EBI (https://www.ebi.ac.uk/Tools/msa/muscle/) (Li et al. 2015). After alignment, we conducted maximum likelihood analysis on COI and LSU alignments separately on two datasets. The full dataset included all individuals sequenced in this project and some from Genbank to include additional succineid genera (trees shown in Supp. file 2, Supp. file 3: COI, 142 sequences; LSU, 51 sequences). A subset alignment included the focal taxa and few other individuals to provide context (trees shown in Figs 2-3: COI, 34 sequences; LSU, 15 sequences). IQ-TREE ver. 1.6.1 was used to remove identical sequences, for model selection, and to conduct maximum likelihood analysis (Nguyen et al. 2015) and 10000 ultrafast bootstrap approximation (UFBoot2) replicates (Hoang et al. 2018). Ultrafast bootstrapping values were interpreted following the unbiased bootstrapping procedure suggested by Minh et al. (2013). All resulting trees were visualized with Dendroscope ver. 3.5.9 (Huson \& Scornavacca 2012). Tree terminals are labeled with an identification number and locality. Some individuals were initially incorrectly identified based on shell morphology (e.g., as $O$. subeffusum in the Washington D.C. area) but confirmed by DNA and anatomy to be O. salleanum.

To test whether the sequence data support species-level distinction for $O$. salleanum and $O$. effusum we performed species delimitation analyses under different assumptions using the 34-terminal (subset dataset) and 142-terminal (full dataset) COI alignments. First, we used Automated Barcode Gap Discovery (Puillandre et al. 2011) as implemented at the ABGD homepage (https://bioinfo.mnhn.fr/abi/public/abgd/) under the default parameters: $\mathrm{Pmin}=0.001$, Pmax $=0.1$, steps $=10, \mathrm{X}$ (relative gap width $)=1.5, \mathrm{Nb}$ bins (for distance distribution) $=20$, and the Jukes-Cantor (JC69) molecular model. ABGD automates finding of the 'barcoding gap', rather than more simplistic methods that use a set p-distance which can vary among taxa. This analytical method infers the barcode gap from the data (and model) and partitions the dataset, going on to apply this method to all sequences in the tree. This allows the genetic distance

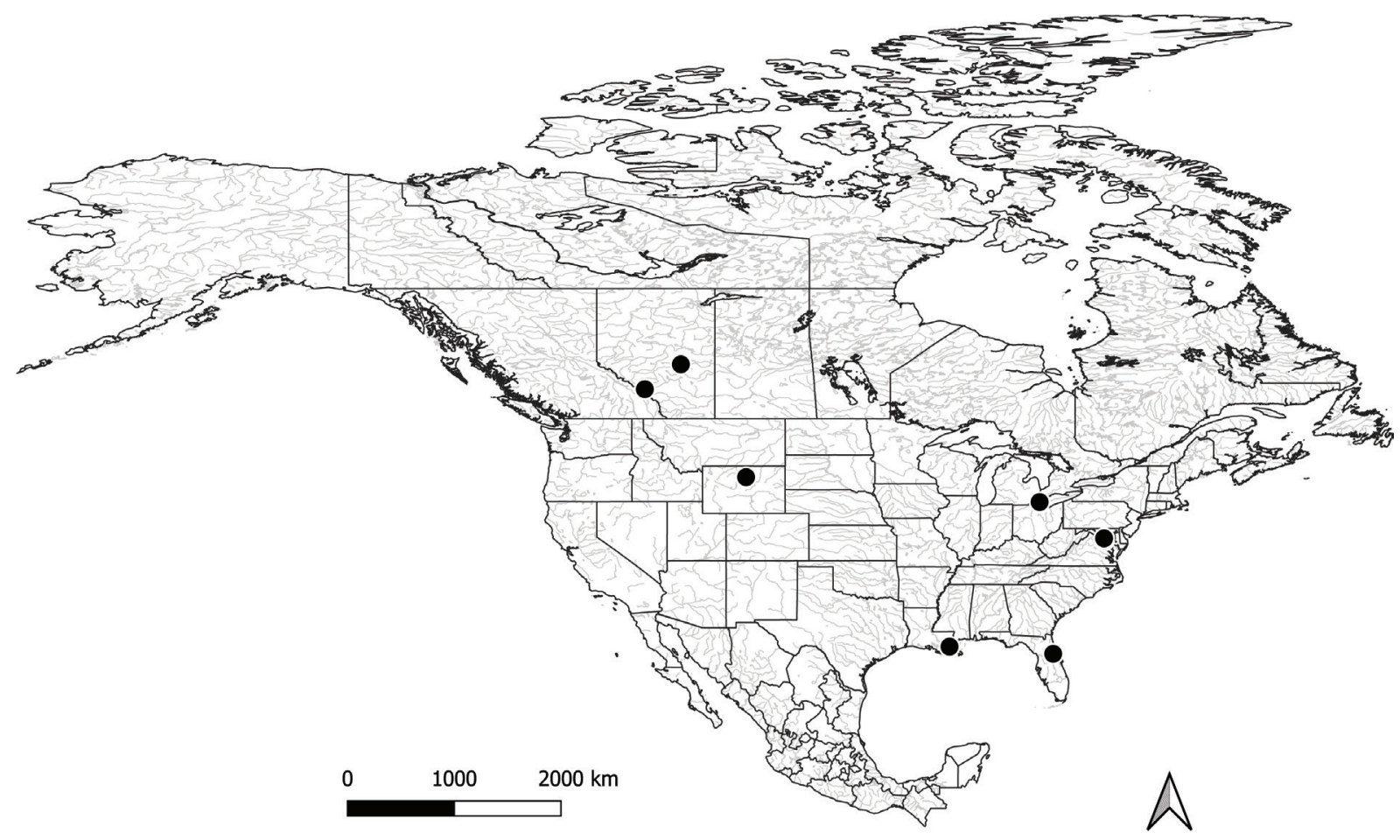

Fig. 1. Map of North America showing confirmed localities for Oxyloma salleana (L. Pfeiffer, 1850). Shown in gray are major rivers (USGS 2004). 
(barcode gap) to infer species boundaries to vary across all taxa in the tree, arranging the sequences into putative species based on this distance (Puillandre et al. 2011). We also assessed delimitation for the resulting hypothetical species-level groups using the Species Delimitation plug-in (SDP) within Geneious (Masters et al. 2011) using the ABGD generated species-clade assignment output as our a priori group assignment (required for this analysis). This procedure tests the monophyly of each specieslabeled group by examining if the grouping is likely to have occurred by chance using the probability of reciprocal monophyly under a random coalescent model (Masters et al. 2011). Using SDP, we separately tested whether all individuals of $O$. salleanum and $O$. effusum were supported as distinct species-level groups. We also used the COI phylogenetic tree produced by IQ-TREE as input data to conduct a multi-rate Poisson tree process (mPTP) model (Kapli et al. 2017) using the Exelixis Lab phylogenetic post-analysis web server (https://cme.h-its.org/exelixis/), mPTP allows each species to have its own evolutionary rate instead of assuming rate homogeneity across all branches.

\section{Geometric morphometrics of shells}

Geometric morphometric analyses were conducted to examine whether shell shape is useful to distinguish $O$. salleanum and $O$. effusum. While broadly conservative in shell form, ambersnails are commonly understood to be hypervariable in shell features, with earlier workers having great difficulty assigning shells to species (Nekola 2014). Due to the difficulty with assigning individuals to species based on the usual taxonomic features of the shells and to minimize variability due to different habitats/ environments, this analysis was limited to individuals with DNA data, and to syntype specimens, and topotypes (specimens obtained from type localities). We also limited the study to mostly unbroken shells of animals assumed to be adult.

The sample of 69 individuals included 19 identified as $O$. effusum and 46 as $O$. salleanum. In addition to recent shells, we also landmarked syntypes of each species and the original shell drawings from each species description (if present). Before landmarking, specimens were randomized and unrandomized following landmarking for further analysis using tpsUtil ver. 1.58 (Rohlf 2006). Using shells aligned horizontally with the apertural opening dorsal, 24 landmarks were placed in tpsDig2 ver. 2.17 (Rohlf 2001) to capture the outline of the shell and shell aperture. Oxyloma shells are quite fragile, particularly $100+$ year old, dried museum specimens, and we found the basal portion of the aperture was often broken. By omitting the outline of this portion of the shell, we were able to include a sufficient sample of shells in this analysis. The analysis included 8 homologous points or Type 1 landmarks, 2 points defined by reference to other points or Type 3 landmarks, and 13 semilandmarks on a curve or Type 4 landmarks by the categorization of Weber \& Bookstein (2011). PAST ver. 3.20 (Hammer et al. 2001) was used for Procrustes superimposition of landmarks, and principal component analysis. A relative warp analysis in tpsRelw ver. 1.65 (Rohlf 1993, 2003), resulting in values identical to a PCA, was used to generate deformation grids to visualize shape differences among species. Geomorph: Geometric Morphometric Analyses of 2D/3D Landmark Data ver. 3.0.6 (Adams et al. 2018) in R (R Core Team 2017) was used to test for differences in mean shape among groups, accounting for allometry, using the morphol.disparity function.

\section{Anatomy}

Comparative anatomical work involved examination of fresh topotype specimens for which we had obtained DNA sequences. We examined external morphology (color and pigmentation patterns; size of body; mucus color), general anatomy (layout of organ systems within the body cavity; branching topology of columellar free retractor muscle system; orientation of kidney and ureter), reproductive system (general organization, and structure of genitalia), jaw (dimensions and ornamentation of cutting plane; relative size and shape of the accessory plate), and radular dentition (number of tooth rows and their orientation; number and form of teeth within transverse rows). Anatomical dissections were performed under a Wild M5 stereo microscope, with specimens in ethanol on a blackened wax base in 
a Petri dish. Particular emphasis will be placed on the structure of the genital anatomy, e.g., size, shape, interrelationships, and ornamentation of the internal, functional surfaces of the penis, epiphallus and vagina (pads; pilasters; transverse, longitudinal or reticulating folds; embedded calcite crystals; chitinous hooks and spines), and the relative position of the opening to the bursa copulatrix, as these features have been shown to be most informative in delineating genus- and species-level taxa in Succineidae (e.g., Patterson 1971). Observations under the stereo microscope were supplemented by examination of tissues under bright-field compound microscope.

\section{Abbreviations}

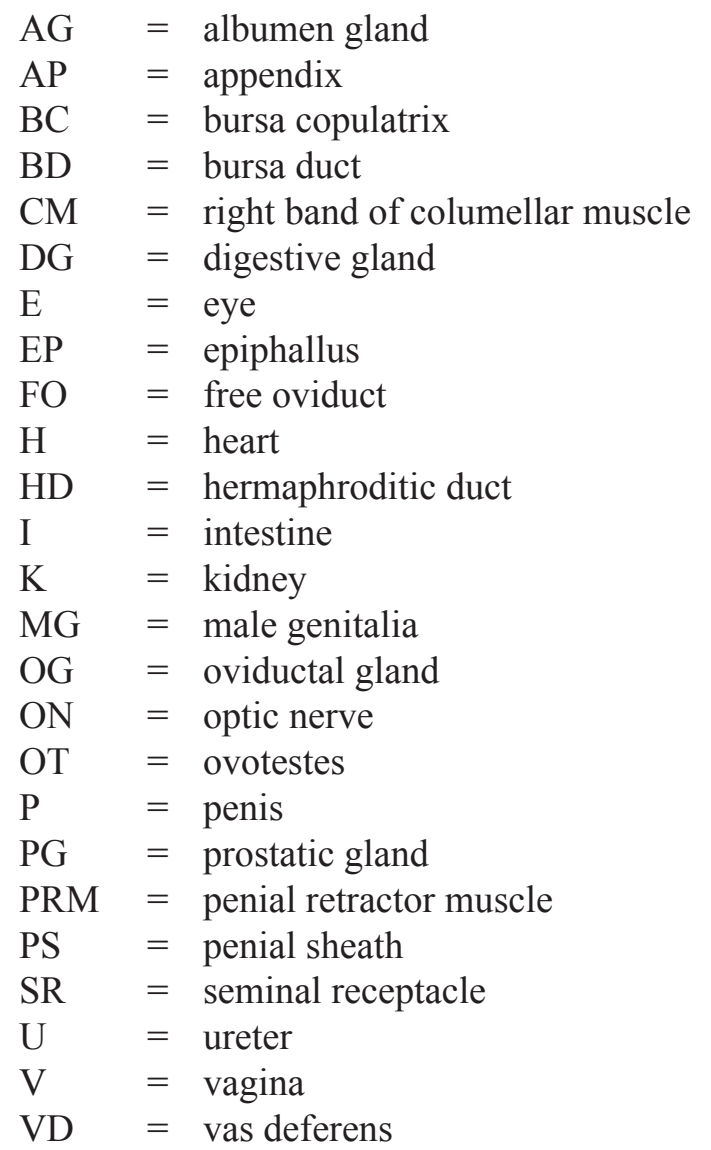

\section{Repositories}

$\mathrm{AMNH}=$ American Museum of Natural History

ANSP $=$ The Academy of Natural Sciences of Drexel University (formerly the Academy of Natural Sciences of Philadelphia)

$\mathrm{CM} \quad=$ Carnegie Museum of Natural History

$\mathrm{FM}=$ Field Museum of Natural History

$\mathrm{NMNH}=$ National Museum of Natural History, Smithsonian Institution

$\mathrm{NMV}=$ National Museum of Victoria, Melbourne

NHMUK $=$ Natural History Museum UK

\section{Results}

\section{Phylogenetic analysis}

The COI alignment consists of $690 \mathrm{bp}$ and the LSU alignment consists of $882 \mathrm{bp}$. To aid visualization of the taxa that are the focus of this manuscript, we figure the COI (Fig. 2; 34-terminals; -2267.018) 


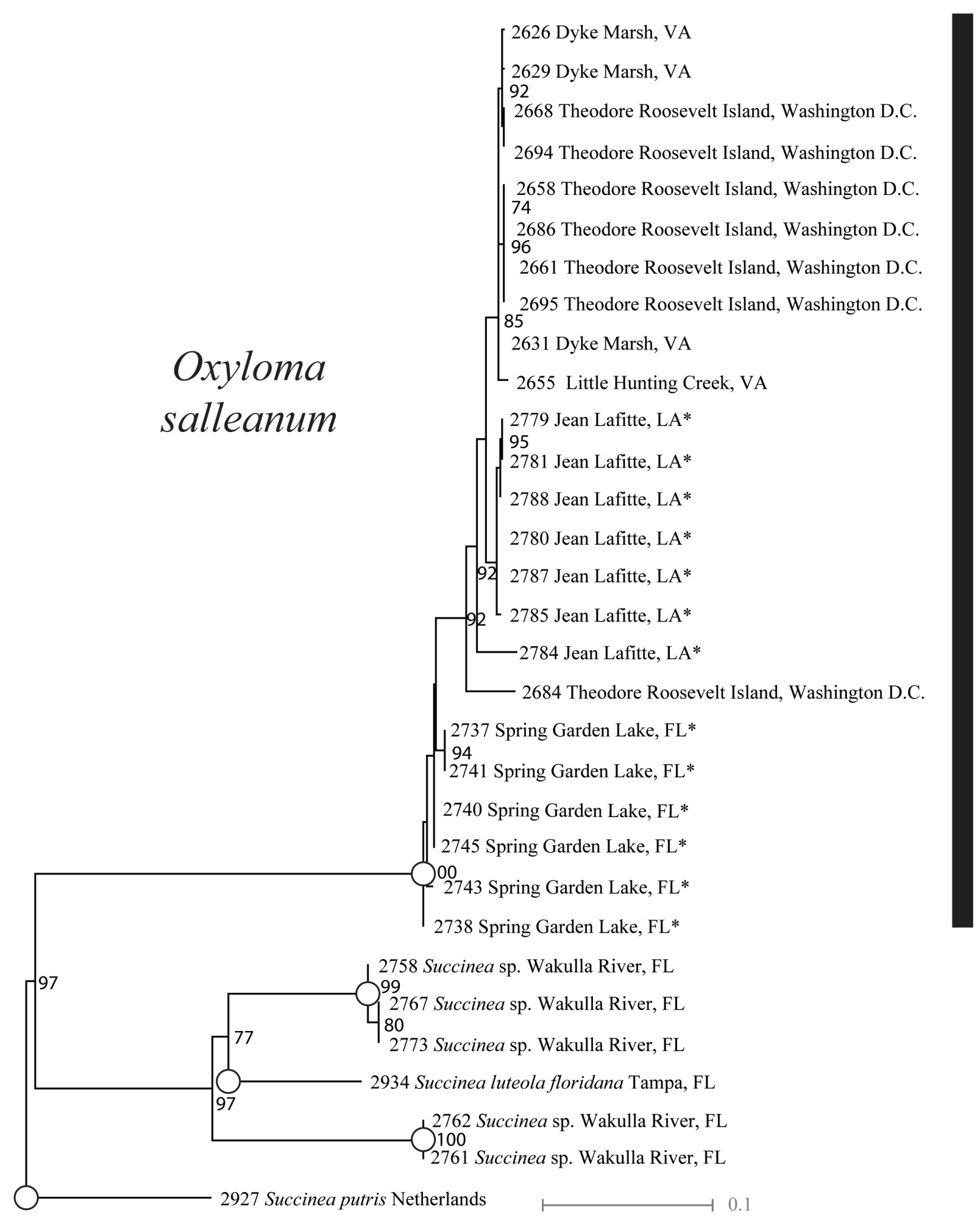

Fig. 2. Maximum likelihood phylogeny from $690 \mathrm{bp}$ alignment of 34 COI sequences presenting only the focal taxa and localities. Ultra-fast bootstrap values indicated behind the nodes supported. Full 142-individual analysis reported in Supp. file 2, Supp. file 3. Type localities indicated with an *. Species supported by species delimitation analyses indicated with a hollow circle. 
and LSU (Fig. 3; 15-terminals; -1554.101) phylogenies, a subset of sequences. COI (Supp. file 2; 142 terminals; -7047.041) and LSU (Supp. file 3; 51-terminals; -2528.571) phylogenies of all sequences generated and GenBank sequences for context are presented as Supplementary files. These expanded trees are not necessary to support our central premise but are useful to share all the information we assembled and point to future areas of taxonomic study. Model selection for each dataset is as follows: 34-terminal COI analysis resulted in the selection of TPM3u+F+R2; 15-terminal LSU analysis resulted in the selection of $\mathrm{HKY}+\mathrm{F}$; 142-terminal $\mathrm{COI}$ analysis resulted in the selection of $\mathrm{K} 3 \mathrm{Pu}+\mathrm{F}+\mathrm{I}+\mathrm{G} 4$; 51-terminal LSU analysis resulted in the selection of $\mathrm{K} 3 \mathrm{Pu}+\mathrm{F}+\mathrm{G} 4$. The 34-terminal COI alignment had 143 distinct patterns, 31 singleton, and 519 constant sites. The 15 -terminal LSU alignment had 66 distinct patterns, 10 singleton, and 828 constant sites. The 142-terminal COI alignment had 346 distinct patterns, 38 singleton, and 395 constant sites. The 51-terminal LSU alignment had 198 distinct patterns, 37 singleton, and 709 constant sites.

Individuals from the type localities of $O$. salleanum and $O$. effusum, and from Washington D.C., Wyoming, and sites in Canada form a well-supported (100\% bootstrap support) shallow clade (Figs 2-3, Supp. file 2). There is some apparent population structure with individuals from each type locality, Jean Lafitte, LA and Spring Garden Lake, FL usually closely related to other individuals that share a locality, however, there are individuals from both type localities scattered throughout this shallow clade. Individuals tentatively identified as O. subeffusum and O. effusum from the area of Washington D.C. (Steury \& Pearce 2014) are

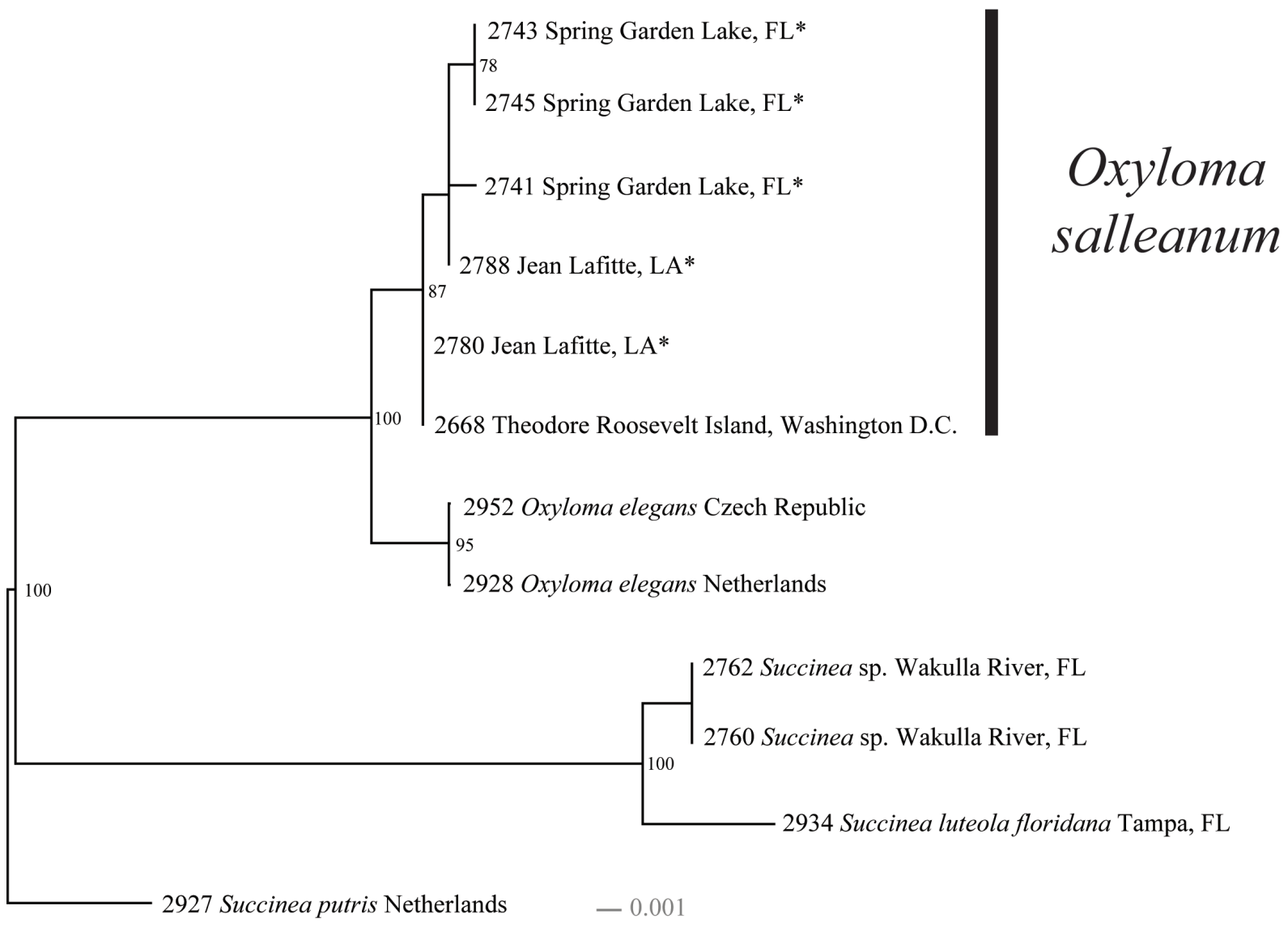

Fig. 3. Maximum likelihood phylogeny from 882 bp alignment of 15 LSU sequences presenting only the focal taxa and localities. Ultra-fast bootstrap values indicated behind the nodes supported. Full 51-individual analysis reported in Supp. file 2, Supp. file 3. Type localities indicated with an * 
also members of this clade. The species delimitation analyses were congruent, none supported specieslevel distinctiveness for $O$. salleanum or $O$. effusum (even when isolated and tested separately) and all supported the species-level distinction of the two combined. In COI, the average pairwise sequence identity (1-p-distance) among $O$. salleanum from the type locality was $97.50 \%$ (Standard Error of the Mean, $\mathrm{SEM} \pm 0.29 \%$ ), among $O$. effusum from the type locality was $96.04 \%$ ( $\mathrm{SEM} \pm 0.14 \%)$. Comparing individuals from the two type localities found a similarity of $96.43 \%$ ( $\mathrm{SEM} \pm 0.15 \%)$. All populations we call $O$. salleanum were $95.55 \%$ similar (SEM $\pm 0.10 \%$ ). In LSU, similarity among $O$. salleanum from the type locality was $98.82 \%$ (SEM $\pm 0.34 \%$ ), among $O$. effusum from the type locality was $97.07 \%$ $(\mathrm{SEM} \pm 0.35 \%)$. Comparing individuals from the two type localities found a similarity of $97.88 \%$ $(\mathrm{SEM} \pm 0.27 \%)$. All populations we call $O$. salleanum were $98.75 \%$ similar (SEM $\pm 0.13 \%)$. In $\mathrm{LSU}$, there were two distinct patterns of indels in the O. salleanum clade, one (a large insertion at the end of ITS2) was shared by all individuals from the two type localities, a few individuals from Washington, D.C, and one individual of $O$. elegans (2928, Netherlands). The clades from the Wakulla River, Ohio, USA, and New Jersey, USA each had distinct patterns of indels (clades shown in Supp. file 3).

The clade of $O$. salleanum + O. effusum is found in a clade with O. elegans from Europe (Supp. file 3), supporting placement in Oxyloma. The LSU sequences (COI was not available) of the two individuals of O. elegans were $95.57 \%$ similar to each other and averaged $96.74 \%$ similar to all $O$. salleana individuals. This study includes just two LSU sequences of $O$. elegans, therefore, it is not clear from this limited sampling if this taxon is distinct, or the same species or subspecies as $O$. salleanum $+O$. effusum. Sister to the Oxyloma clade are succineids from Florida and Europe. The relationships were slightly different among the two genes for each of these species: Succineidae sp. 1 \& 2 Wakulla River, FL, Succinea luteola Gould, 1848, and Succinea putris (Linnaeus, 1758) - attributable to limited phylogenetic information in the LSU dataset but worth future study. They were also supported by all species delimitation analyses but are not discussed further here.

\section{Geometric morphometrics of shells}

We used specimens from the type localities of $O$. salleanum and $O$. effusum to see if they are distinguishable by shell. Other populations could not be incorporated because identifications confirmed by DNA and anatomy were not available. A principal components analysis (Fig. 4A) of Procrustestransformed landmark data finds one significant principal component. PC1 accounts for $51.34 \%$ of the variance and PC2 for $18.50 \%$, and PC3 for $10.45 \%$. As shown in Fig. 4A, topotypical individuals representing $O$. salleanum and $O$. effusum form distinct but overlapping clouds, indicating that the shapes can be distinguished but some individuals from each population fall into the general shape of the other population. Fig. 4A also illustrates the differences in shape for the mean of each species compared to a consensus shape (wire diagrams). Fig. 4B illustrates the shape difference using the wire diagrams overlayed and with a deformation grid. These illustrations show that $O$. effusum has a narrower body whorl and a wider aperture relative to $O$. salleanum, but they are similar in shape. A pairwise comparison finds the populations significantly different in mean shape at $\mathrm{p}<0.001$ with a small effect size $(Z=5.462)$. Examining the effect of centroid size when accounting for group membership indicates that populations do not differ significantly in size (pairwise comparison $\mathrm{p}>0.05$ ). The types of the two taxa (Fig. 4A) fall near but slightly outside the convex hulls drawn around the shells of their respective group. The original illustration of $O$. salleanum (L. Pfeiffer 1850) falls inside the convex hull of that taxon, but the original illustration of $O$. effusum falls far outside either group.

\section{Anatomy}

We examined the anatomy of $O$. salleanum and $O$. effusum sampled only from the respective type localities of Jean Lafitte, LA and Spring Garden Lake, FL (Figs 5-7). Thus, we have been unable to fully characterise the variation in anatomical characters considered diagnostic at species level. However, our anatomical examination of topotypic $O$. salleanum and $O$. effusum clearly shows these two taxa to be 
A

O. salleanum O. effusum
O. salleanum fig. O. effusum fig.
B

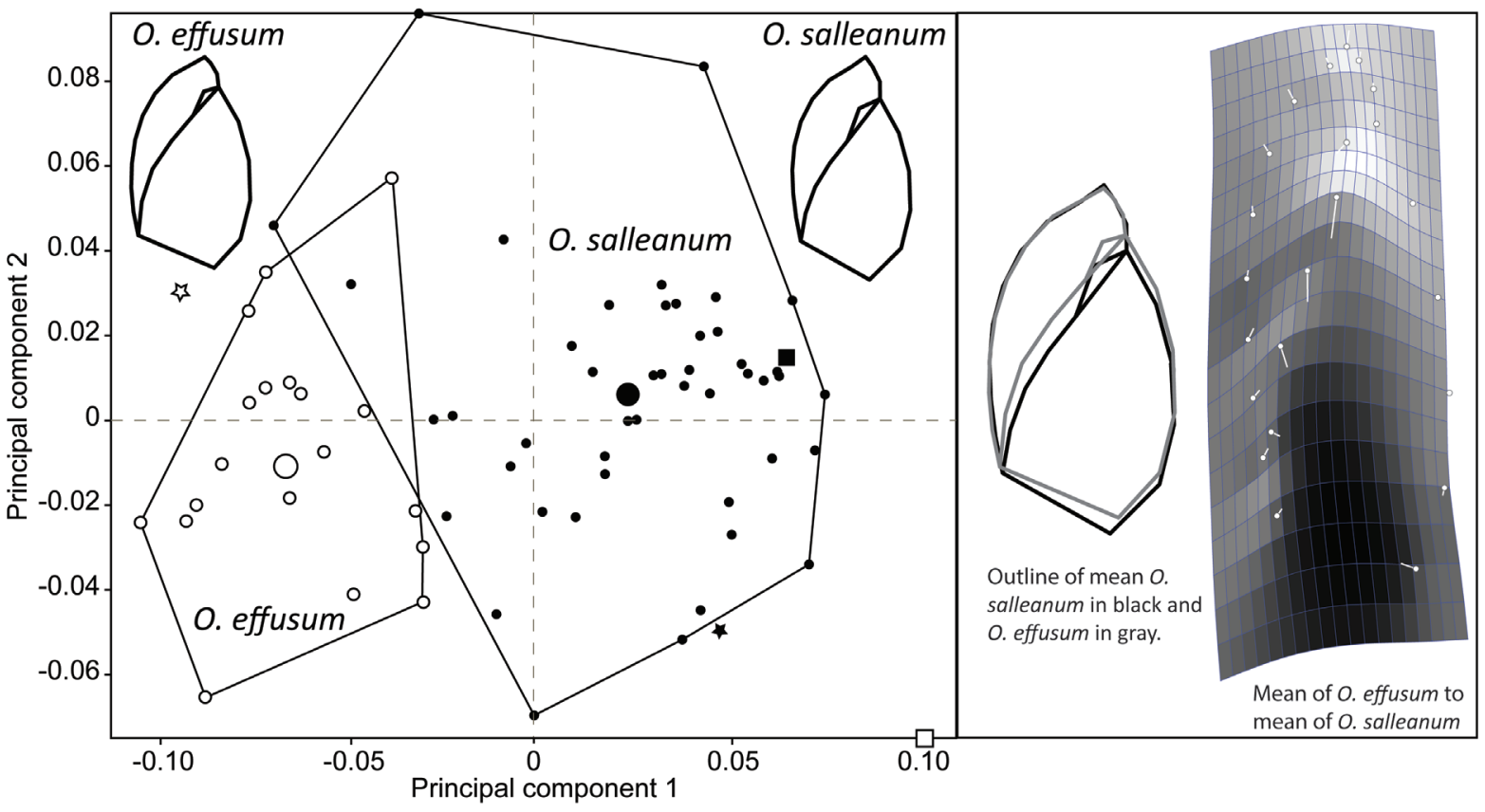

Fig. 4. A. Plot of principal component analysis on Oxyloma effusum (L. Pfeiffer, 1853) (n = 19) and O. salleanum (L. Pfeiffer, 1850) $(\mathrm{n}=46)$ shells collected from the type localities. Landmarked types and original figures are included for each species. Convex hulls are drawn from non-type shells examined. The centroid means of each species shown with oversize symbol. Outline drawings represent the mean form of each nominal species compared to the overall mean shape. B. The outlines of the two nominal species superimposed with $O$. salleanum in black and $O$. effusum in gray. The heat map deformation grid shows the shape change from the mean form of $O$. effusum to the mean form of $O$. salleanum. Vectors on landmarks show the direction and magnitude of change.

conspecific in sharing a characteristic folding of the free oviduct, and an elongated fecundation pouch manifest in the seminal receptacles being placed towards the distal extremity of the albumen gland. The male genitalia exhibited high similarity between these taxa in relative size, shape, internal longitudinal folds studded with calcite rosettes, form of the penial appendix and vergic papillum, and despite some infra-population variation, in coiling of both epiphallus and penis within the penial sheath. For further details of the anatomy, see Systematic section below.

\section{Systematic account}

Phylum Mollusca Linnaeus, 1758

Class Gastropoda Cuvier, 1795

Subclass Heterobranchia J.E. Gray, 1840

Order Stylommatophora A. Schmidt, 1855

Superfamily Succineoidea Beck, 1837

Family Succineidae Beck, 1837

Genus Oxyloma Westerlund, 1885

Succinea (Oxyloma) Westerlund, 1885: 1, 7. 


\section{Type species}

Succinea dunkeri L. Pfeiffer, 1865, subsequent designated by Westerlund (1885). Gender: Neuter.

\section{Remarks}

Readily distinguished anatomically from other succineid genera by presence of a digiform appendix opening to the proximal apex of the penis.

Subgenus Neoxyloma Pilsbry, 1948

Oxyloma (Neoxyloma) Pilsbry, 1948: 775, 777.

\section{Type species}

Succinea effusa L. Pfeiffer, 1853 by original designation.

\section{Remarks}

The degree of coiling and folding of the epiphallus was used by Pilsbry (1948) as the sole anatomical character to separate Neoxyloma from Oxyloma s. str. The validity of this classification schema has yet to be properly evaluated with molecular phylogenetic and anatomical analyses.

\section{Oxyloma salleanum (L. Pfeiffer, 1850)}

Figs 5-8

Succinea salleana L. Pfeiffer, 1850: 133.

Succinea effusa L. Pfeiffer, 1853: 17. syn. nov.

\section{Material examined}

\section{Syntypes}

UNITED STATES OF AMERICA • 3 adult specs (Succinea salleanum); Louisiana, New Orleans; Cuming Collection ex Sallé; NHMUK 20170302 - 5 adult specs (Succinea effusum); Florida, East Florida; Cuming Collection, ex R.J. Shuttleworth; NHMUK 20170303.

\section{Additional material}

UNITED STATES OF AMERICA - 26 adult specimens; Louisiana, intracoastal waterway at Lake Salvador, near Jean Lafitte; $29.741947^{\circ}$ N, -90.141741 ${ }^{\circ}$ W; 29 Jun. 2017; Marco Martinez Cruz and Kathryn E. Perez leg.; CM 164850 to CM 164975 (detailed in Supp. file 1) • 19 adult specs; Florida, Spring Garden Lake; $29.136254^{\circ}$ N, $-81.36917^{\circ}$ W; 27 Jun. 2017; Marco Martinez Cruz and Kathryn E. Perez leg.; CM 164905 to CM 164915 (detailed in Supp. file 1) • 198 adult specs; Louisiana, Kenner, near river; 25 Nov. 1961; L. Hubricht leg.; FM 235556 30 adult specs; Louisiana, Alexandria, near Red River, foot of Monroe Street; 7 Apr. 1962; L. Hubricht leg.; FM $235557 \bullet 40$ adult specs; Louisiana, near Lake Providence, near Highland; 24 Sep. 1969; L. Hubricht leg.; FM 235558 • 8 adult specs; Louisiana, Lake Beresford; FM 144852 • 6 adult specs; same collection data as for preceding; FM 103925.

\section{Original descriptions}

Succinea salleana L. Pfeiffer, 1850

"S. testâ depressè ovatâ, tenuissimâ, striatulâ, lineis spiralibus, impressis irregulariter notatâ, pellucidâ, nitidâ, corneo-albidâ; spirâ brevissimâ, subpapillatâ; anfractibus $2 \frac{1}{2}$, penultimo convexo, ultimo $3 / 4$ longitudinis superante; columellâ subcallosâ, strictè recedente; aperturâ axis subparallelâ, angulato-ovali; peristomate submarginato, margine dextro vix arcuato. Long. 19, diam. 10, alt. 7 mill.; ap. 16 mill. longa, infra medium 9 lata. [Shell depressed ovate, very thin, weakly striate and marked with irregular spiral 
lines, transparent, glossy, corneous whitish; spire very short, subpapillate; whorls $2 \frac{1}{2}$, the penultimate convex, the last exceeding three quarters the length of overall shell length; columella somewhat calloused, strictly receding; aperture subparallel with the axis, strongly angulate, oval; peristome submarginate, the right margin slightly arcuate. Length $19 \mathrm{~mm}$, diameter $10 \mathrm{~mm}$, depth $7 \mathrm{~mm}$, aperture $16 \mathrm{~mm}$ long, $9 \mathrm{~mm}$ wide below middle]. Hab. New Orleans [Louisiana, USA] (Mr. [Auguste] Sallé)."

\section{Succinea effusa L. Pfeiffer, 1853}

"T. depresso-ovata, tenuissima, striatula, parum nitens, diaphana, griseo-cornea; spira brevissima, acuta; anfr. 21/2, ultimus magnus, depressus, $5 / 6$ longitudinis aequans; columella vix arcuata, subrecedens; apertura ampla, obliqua, ovalis; perist. simplex, regulariter arcuatum, basi non incumbens. Long. 12, diam. 7, alt. 41/2 mill. Ap. 10 mill. longa, 6 lata. [Shell depressed ovate, very thin, delicately striate, a little glossy, diaphanous, grayish-brown colored. Spire extremely short, acute; whorls $2 \frac{1}{2}$, the last large, depressed, five-sixth of shell length; columella scarely arcuate, subreceding; aperture ample, oblique, oval; peristome simple, regularly arcuate. Length $12 \mathrm{~mm}$, diameter $7 \mathrm{~mm}$, depth $4.5 \mathrm{~mm}$, aperture $10 \mathrm{~mm}$ long, $6 \mathrm{~mm}$ wide] (Mus. Cuming.) Succinea effusa Shuttl. [Shuttleworth] mss. Habitat in Florida orientali."

\section{Redescription}

SHELl (Fig. 5). Medium to large, succiniform, imperforate, oval shape, very thin and delicate, often fractures when handled, glossy, translucent, horn to straw-yellow, spire short to very short (0.75-0.83 of total shell height); entire shell with 2.5-3 whorls, body whorl very large, penultimate and early part of body whorl with small papillae, irregular and variable among individuals; growth lines visible on body whorl, as often are coarse wrinkles, and sometimes with traces of spiral lirae; embryonic whorl smooth until papillae begin (if present); some individuals with light variable spiral lines; aperture large, tear drop in shape, base of aperture flatter and receding, lip is not reflected, however along the columellar axis the shell edge rounds inwards. Shell capable of fully housing the retracted animal. Average shell height $=12.95 \mathrm{~mm}$, average shell width $=6.91 \mathrm{~mm}$, aperture height $=10.51 \mathrm{~mm}$, aperture width $=$ $5.85 \mathrm{~mm} ; 2.54$ whorls. Shells measured ( $\mathrm{n}=21$ total) were from the DNA numbers 2813, 2812, 2958, 2757, 2956, 2754, 2752, 2756 and Field Museum of Natural History (FM) 235556 ( $\mathrm{n}=14)$.

Animal external morphology. Anterior face of head bearing paired ocular peduncles, each with eye at the apex, and more ventrally paired inferior tentacles. Foot broad, tail extending behind shell in active animals. On each side of foot, a shallow pedal groove just above the margin with the sole; sole tripartite. Head, base of ocular peduncles and sides of foot not heavily pigmented, with brown, grey to black flecks; head flecking tending to be aggregated into posteriorly directed bands. Mantle collar and mantle pigmentation highly variable but never intense; speckling of brown and grey irregularly aggregated along mantle collar and adjacent anterior margin of mantle, becoming more diffuse over pallial cavity and very weak over kidney and viscera. Sole unpigmented in the examined animals.

REPRODUCTIVE ORGANS (Figs 6-8). Lying predominately in the right side of the body cavity, more-orless close to and parallel to the columellar axis; in mature animals all other organs (other than pallial) are ventral or ventro-lateral to the reproductive system; genitalia extending diagonally across the body cavity. Ovotestis (gonad) largely confined within shell spire but extending into body whorl in mature animals, partially embedded in upper lobe of digestive gland, comprising a mass of densely clustered acini. Hermaphroditic duct running forward along columellar axis; expanded, highly convoluted as seminal vesicle in medial section; narrowing and less convoluted to reach carrefour region appressed to columellar surface of albumen gland; seminal receptacles paired, often unequally in length, their apices rounded and separate but otherwise the receptacles are united for the greater part of their length, opening into elongate saccular fecundation pouch to extend to origin of pallial gonoducts. Male and female gonoducts semi-diaulic in that spermiduct initially comprising a ciliated groove on the ventral floor of 

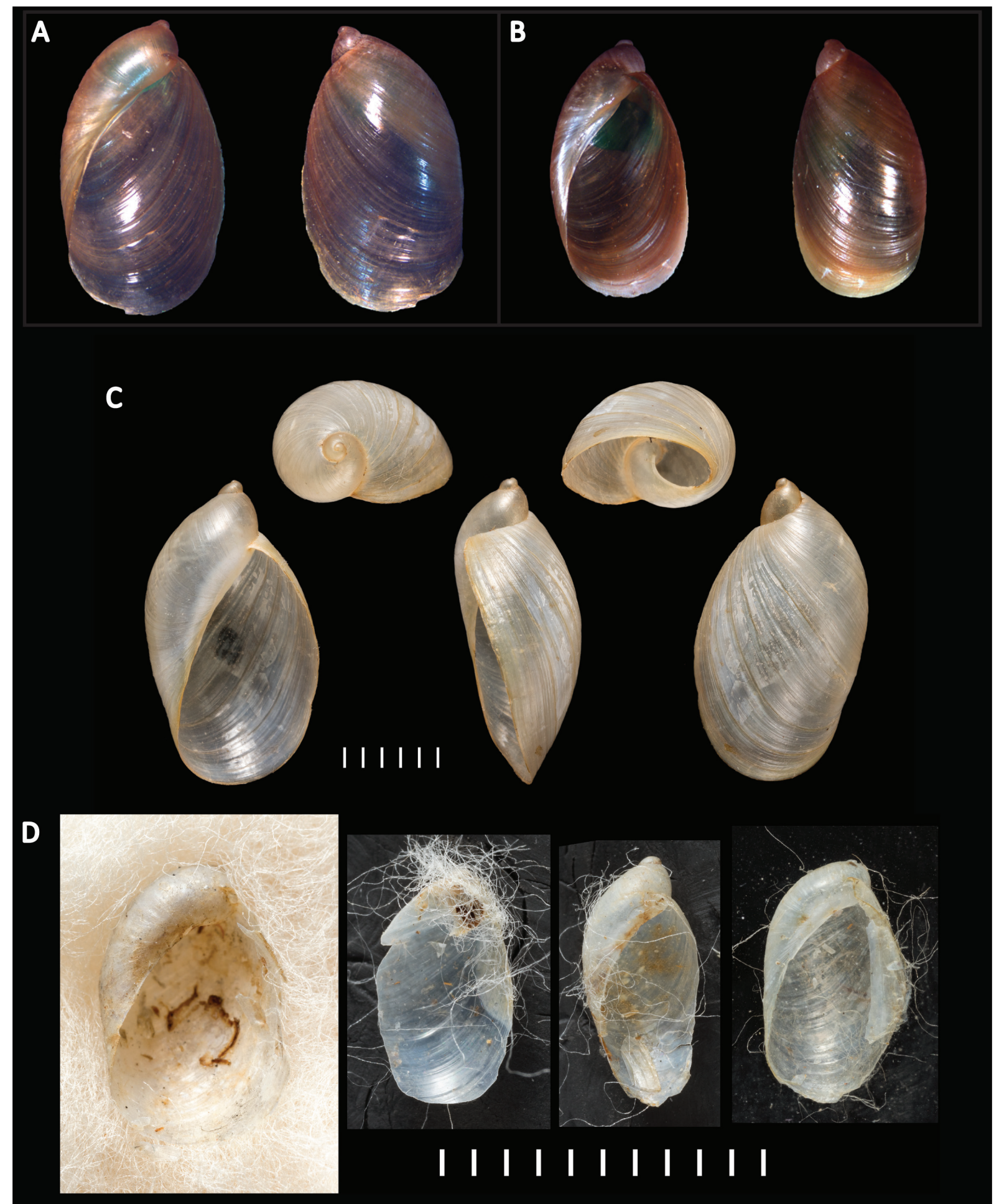

Fig. 5. Apertural and reverse view of shell of Oxyloma salleanum (L. Pfeiffer, 1850) and O. effusum (L. Pfeiffer, 1853). A. Photograph of Oxyloma effusum shell taken from the type locality in eastern Florida. Shell is $11.28 \mathrm{~mm}$ total height. B. Photograph of Oxyloma salleanum shell taken from the type locality near New Orleans, Louisiana. Shell is $13.11 \mathrm{~mm}$ total height. C. Syntypes of Oxyloma salleanum (NHMUK \# 20170302). D. Syntypes of Oxyloma effusum (NHMUK \# 20170303). Scale bars $=1 \mathrm{~mm}$. 
the female pallial gonoduct, forming a short spermoviduct before separating as a long slender duct, the vas deferens, running forward along the female pallial gonoduct before recurving to run along the face of the penial sheath into which it penetrates apically adjacent to the insertion of the penial retractor muscle. Prostatic gland a large more-or-less oval mass of fine acini partially enclosing and opening to the initial free part of the vas deferens. Vas deferens with ciliated lumen, but distally differentiated as an epiphallus with more muscular walls and folded internal lumen. Epiphallus convoluted, narrow proximally but broadening rapidly and then of more-or-less uniform width to run to penis into which it opens as a short but often distinct vergic papillum. Penial appendix opening at proximal end of penis, adjacent to vergic papillum; appendix digiform, short, more-or-less straight and uniform in width throughout length except rounded apex slightly dilated and reflected; appendix everting and functioning as a flagellate appendage during copulation. Penis more-or-less straight and of uniform width; wall of penial chamber thrown into several low longitudinal folds, smooth but for being weakly to densely studded with minute calcite rosettes; there is no proximal-distal differentiation in penial morphology. Penis and epiphallus entirely enclosed within a thin muscular sheath, which at the vas deferens-epiphallus junction gives rise to the penial retractor muscle that extends posteriorly to the right side of the body cavity, passing below the intestinal anterior loop to attach to the dorsal body wall. Albumen gland ovate in immature individuals, becoming large, linguiform on maturity, opening through a single channel to distal part of fecundation pouch. Female pallial gonoduct proximally an oviductal gland comprising sacculated, voluminous folds whose folds are more-or-less tangential to the long axis and regionally differentiated with several types of secretory cells. Distally, female gonoduct becomes narrower, free of secretory cells, with muscular walls; as free oviduct slender and folded above entry of the duct of the bursa copulatrix; as vagina stout, broader and straight below, opening into common reproductive orifice with male genitalia at anterio-lateral aspect of the animal behind the right ocular tentacle; male genitalia opening dorsal to

A

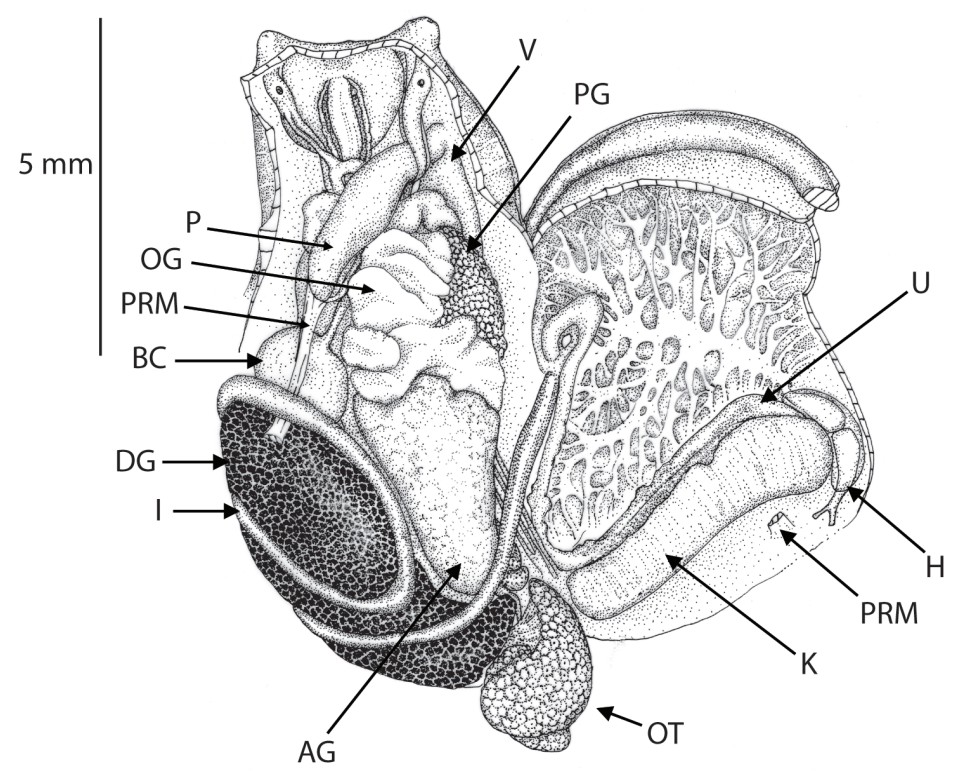

B

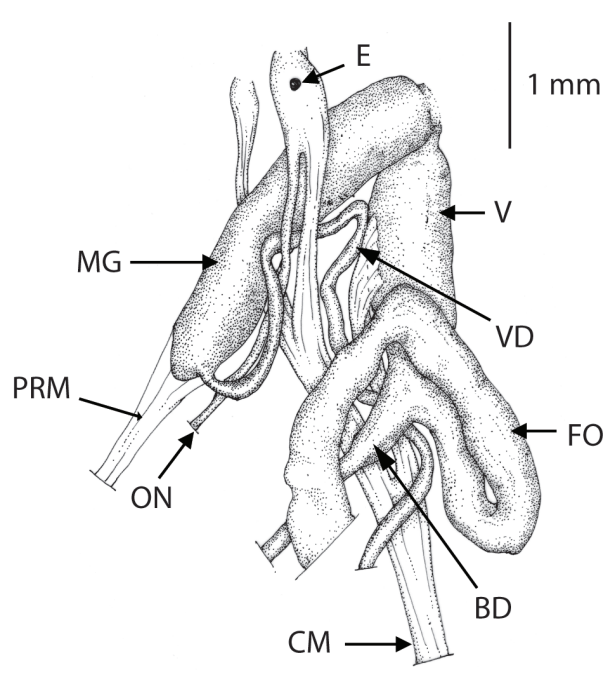

Fig. 6. Oxyloma salleanum (L. Pfeiffer, 1850). Intracoastal waterway at Lake Salvador, near Jean Lafitte, Louisiana, specimen 2789 (NMV F 304257, shell height $10.55 \mathrm{~mm}$ ). A. Dissected animal, with mantle reflected to right to show general layout of organs within body cavity, and organs of mantle cavity in ventral view. B. Genitalia in situ, showing route of right band of the columellar muscle, over male genitalia to reach right ocular peduncle, with branch passing under male genitalia to reach right inferior tentacle, and a lateral branch to insert on vagina. Abbreviations: see Material and methods. 
the female vagina within this common orifice. Bursa duct distinctly broader, more muscular for initial part from free oviduct then slender, thin-walled extending to large oval bursa sac; bursa copulatrix duct extending diagonally across the body cavity, below the anterior loop of the intestine and the penial retractor muscle, such that the sac is ventral to and closely associated with the pericardium. Distal section of vagina, near genital orifice, equipped with thin retractor muscle running posterior-ventrally to body wall. Thin connective tissue encasing the reproductive organs; pigmented with grey-brown and black speckling over penis, distal section of vas deferens (some specimens), ovotestis, hermaphroditic duct and seminal receptacles, and less frequently and less intensely over prostatic gland; pigmentation most intense - approaching intense black in some individuals - over midsection (seminal vesicle) of hermaphroditic duct and the apices of the seminal receptacles.

FREE MUSCLE SYSTEM. Right branch of the columellar free retractor system, either free from near origin in columella or as a branch from the buccal retractor stem, anteriorly passes between male and female genitals, runs over the male genitalia to insert in the right ocular tentacle; smaller anterior branch passing under male genitalia to attach to right inferior tentacle and right floor of the body cavity lateral to buccal mass.

\section{HAPLoID CHROMOSOME NUMBER. 19 (Burch et al. 1966; Patterson 1971)}

Digestive system. Buccal mass equipped with jaw and radula. Jaw elasmognathous in having an accessory dorsal plate; cutting piece scribing a broad arc, with broad concave anterior margin, its lateral extremities rounded, and with small medial projection and less frequently with additional ribs. Radula tending to increase in size with animal size, reaching 90 to 130 transverse rows of teeth, each with 90 to 110 teeth; central tooth tricuspid, with large mesocone flanked on either side by a short ectocone; lateral teeth bicuspid with large mesocone and small ectocone; on transition to marginal teeth at the
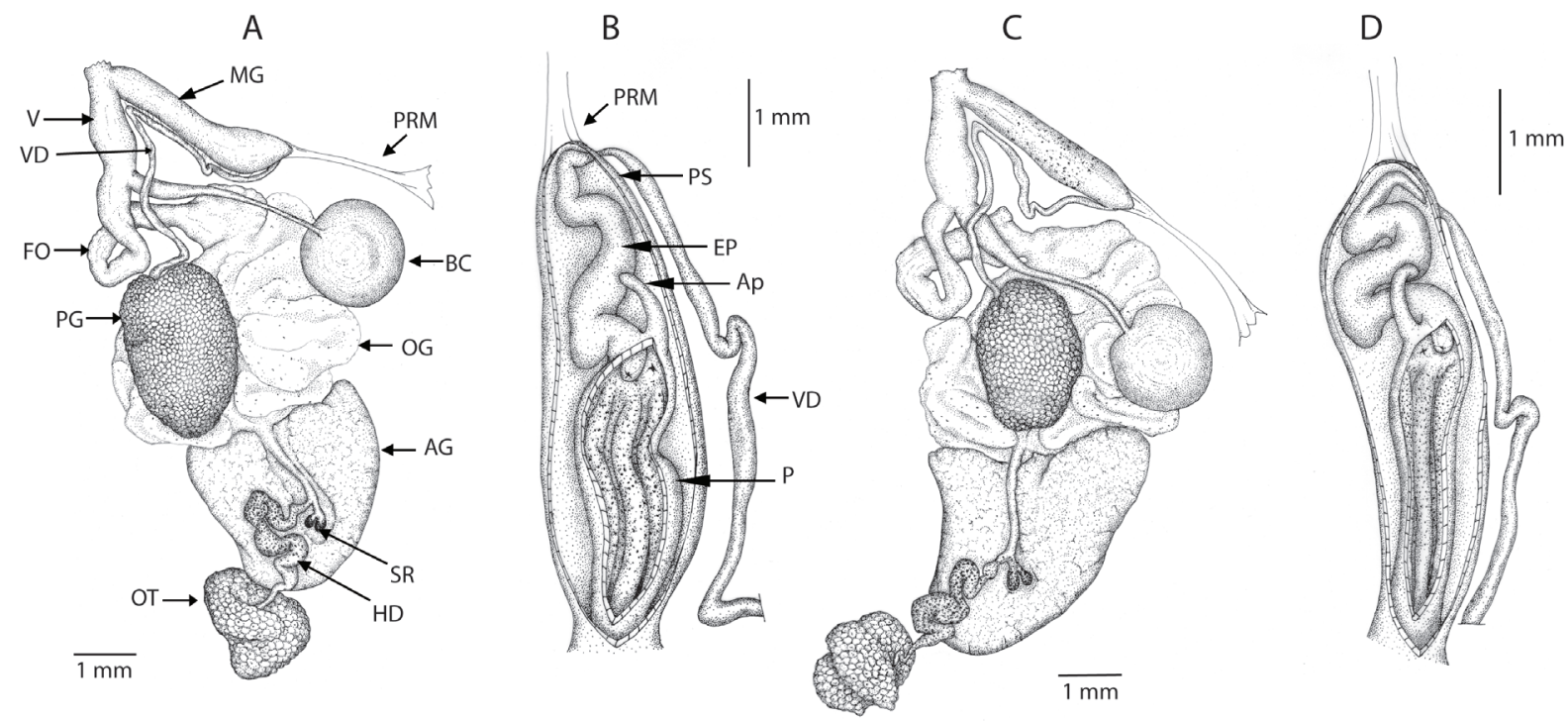

Fig. 7. Oxyloma salleanum (L. Pfeiffer, 1850). Intracoastal waterway at Lake Salvador, near Jean Lafitte, Louisiana. A-B. Reproductive organs of specimen 2789 (NMV F 304257, shell height $10.55 \mathrm{~mm}$ ), in ventral view, and male genitalia. C-D. Reproductive organs of specimen 2788 (NMV F 304256, $10.1 \mathrm{~mm}$ ), in ventral view, and male genitalia. Details of the male genitalia (B, D), with penial sheath opened to expose the epiphallus and penis with proximal appendix. Penis opened to show the spatial relationships of appendix and epiphallus openings to proximal penis, and the longitudinal folds bearing calcite rosettes embedded in the epithelium. Abbreviations: see Material and methods. 
radula lateral edges, mesocone reducing in size and subdividing, and ectocone subdividing. Oesophagus arising from dorsal aspect of buccal mas, passes through CNS to dilate as esophageal crop before narrowing posteriorly to stomach. Stomach a simple curvature with oesophageal and intestinal openings at respective extremities; ducts of anterior and posterior lobes of digestive gland open into concave midregion; a small caecum associated with duct of the anterior lobe of the digestive gland. Intestine with one forward-directed loop, turning posterior after crossing over the aorta and running posteriorly to form a single posterior loop before running forward to the anus; intestine not coiling around oesophageal crop.

Pallial organs. Pallial cavity short, broad, richly vascularized. Pericardium at left lateral aspect of pallial cavity, abutting kidney to which it communicates by a very short renopericardial duct; containing heart, with auricle anteriad receiving the pulmonary vascular network; ventricle posteriad, orientated more-or-less parallel with long axis of body, giving rise to aorta that passes over the anterior intestinal loop before dividing into anterior and posterior aortic branches. Kidney elongate, transverse in respect to body axis and orientated posteriad to reach right extremity of the pallial cavity. Ureter arising from left anterior extremity of kidney, elongate, tubular, extending along anterior face of kidney to reach posterior extremity of the pallial cavity on right, then recurving anteriorly to run more-or-less adjacent to and above rectum to excretory orifice immediately anterior to the pneumostome; terminal part of ureter, above the pneumostome, is continued forward as a blind bladder-like caecum.

\section{Distribution and habitat}

Distribution confirmed here with DNA sequence data includes USA: Florida, Louisiana, Washington D.C., Wyoming, Virginia; CAN: Alberta, Ontario.

A

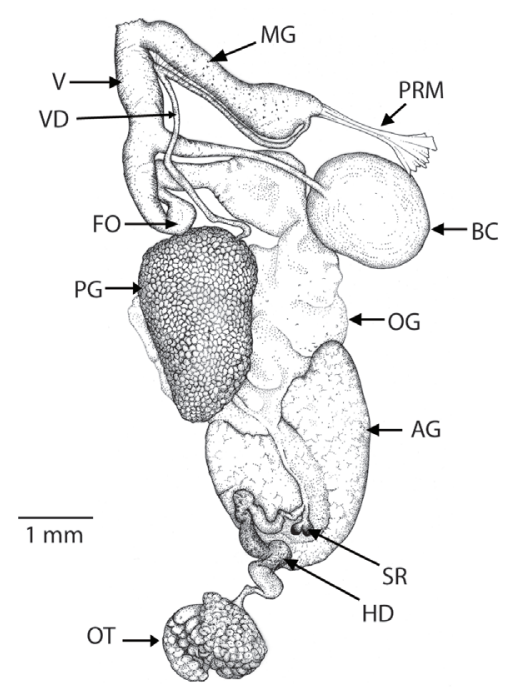

B

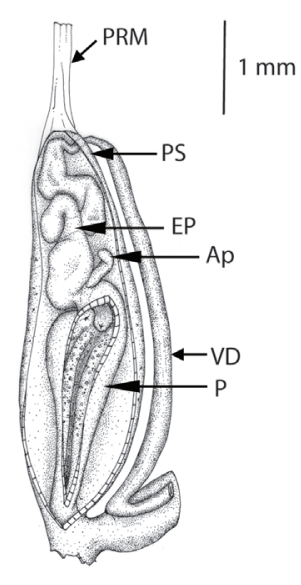

C

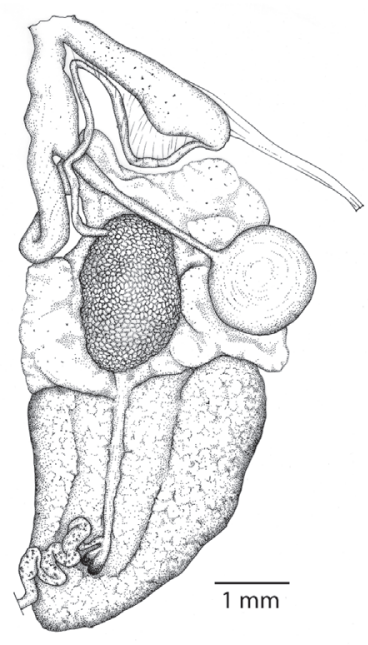

D

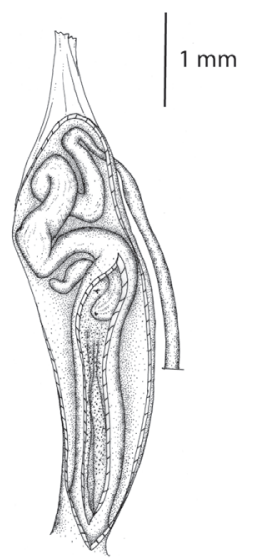

Fig. 8. Oxyloma salleanum (L. Pfeiffer, 1850). Spring Garden Lake, Volusia County, Florida [O. effusum (L. Pfeiffer, 1853) topotypes]. A-B. Reproductive organs of specimen 2737 (NMV F 304258, shell height $11.0 \mathrm{~mm}$ ) in ventral view, and male genitalia. C-D. Reproductive organs of specimen 2745 (NMV F 304259, $11.7 \mathrm{~mm}$ ) in ventral view, and male genitalia. Details of the male genitalia of specimens 2737 and 2745 (B, D), with penial sheath opened to expose the epiphallus and penis with proximal appendix. Penis opened to show the spatial relationships of appendix and epiphallus openings to proximal penis, and the longitudinal folds bearing calcite rosettes embedded in the epithelium. Abbreviations: see Material and methods. 


\section{Taxonomic remarks}

From the Hugh Cuming Collection in NHMUK, Pfeiffer (1850) described his new species Succinea salleana, based on specimens collected from New Orleans by Auguste Sallé. Pfeiffer (1850) neither mentioned the number of specimens available to him in erecting $S$. salleana nor did he publish any illustration of the type material. Subsequently, Pfeiffer (1855: 49, pl. 5 figs 7-8) published two figures (apertural and reverse views) of a single shell. In an original illustration, Reeve (1873: pl. 6 fig. 40a-b) likewise depicted two views of a shell of $S$. salleana from NHMUK. The NHMUK material acquired by Cuming from Salle likely formed the basis of the shell material illustrated by Pfeiffer (1855) and Reeve (1873). Three syntype (dry shell) specimens of Succinea salleana are presently in NHMUK 20170302. In an early American account of the species, Binney \& Bland (1869: 270, text-fig. 486) had no material of $S$. salleana but reproduced Pfeiffer's (1850) original description and provided an illustration of the shell based on Pfeiffer (1855). Later, Binney (1878: 42, pl. 79 fig. 18) and Binney (1885: 443, textfig. 488) also reproduced Pfeiffer's (1850) original description. These authors made no mention of having examined specimen material of the species, yet the identical illustration of the shell was not reproduced from Pfeiffer (1855) but evidently based on examined specimens. Gratacap (1901) states that two specimens in the AMNH, namely 2137 and 2138 from Alexandria and New Orleans (Louisiana) respectively, correspond to the material of Binney (1878), with AMNH 2137 being the specimen illustrated. AMNH 2137 has no type status, but AMNH 2138 may be a syntype as part of Auguste Sallé's original collection. As was common practice during the $19^{\text {th }}$ century, part of the lot of specimens collected by Sallé may have been dispersed on exchange or gift to other collectors and museums. Binney (1885: 498), in a tabulation of the Binney Collection, listed one specimen of S. salleana (Colln. No. 39783) from "New Orleans" ex "Sallé to Bland" as "original lot". These specimens of possible syntype status, currently in NMNH 39783 and AMNH 2138, have not been sighted in the present work.

The original definition of the type locality of Succinea salleana was simply New Orleans. Additional material of Sallé were not found to establish a more precise type locality. Just south of New Orleans, west of the Missisippi River, we located large populations of ambersnails matching the description of $S$. salleana in Lake Salvador among cattails and on the banks of the lake. Pilsbry (1948) made no reference to the type material of $S$. salleana and thus it can be assumed that it was not examined. His referral of specimens from New Orleans to $S$. salleana, and others from Frierson Louisiana, Crève Coeur Lake Missouri, and Samburg Tennessee were thus evidently based on prevailing taxonomic wisdom founded on the conchological features described and illustrated by Pfeiffer $(1850,1855)$ and subsequent authors. Pilsbry (1948: 793, fig. 422d) was the first to anatomically examine material referred to $S$. salleana, based on preserved specimens from the west side of the Mississippi River, New Orleans (ANSP 60930 ex ANSP 60931, collected Pilsbry 1889) [ANSP 60931 is listed in error as 'type' in the museum database]. Features of the reproductive anatomy lead Pilsbry (1948) to transfer S. salleana to Oxyloma.

Pfeiffer (1853) described Succinea effusa as a new species based on specimen material in the Hugh Cuming Collection in NHMUK originating from Robert J. Shuttleworth. The collector of the specimens from "Florida orientali" [eastern Florida] is unproven, as is the precise type locality. In describing this species, Pfeiffer (1853: 17) explicitly stated that Shuttleworth was responsible for the specific name in an unpublished manuscript, list or specimen label ("Succina effusa Shuttl. mss."). Nonetheless, Pfeiffer $(1853,1855)$ explicitly attributes the species to Shuttleworth in the published work (e.g., as Succinea effusa Shuttleworth) and in doing so caused considerable confusion as to the authority of the taxon. Several early workers (e.g., Binney 1885) considered Shuttleworth as the author. However, under ICZN Code, Art. 50, such attribution of authorship for the taxon name alone is not accepted; only authorship for the description is accepted. Accordingly, Pfeiffer (1853) is the author, and this has been recognized in more recent works on Succineidae (e.g., Pilsbry 1948: 788). The syntype material remaining in NHMUK 20170303 comprises five dry shell specimens. It is probable that additional specimens from the original 
collection in Florida are housed in the Shuttleworth collection in the Naturhistorisches Museum Bern, Switzerland, however, this cannot be documented. Naturhistorisches Museum Bern collection number 12772 is part of the Shuttleworth collection and listed as Succinea effusa, with the original label missing. In addition, a lot of Succinea effusa collected by Rugel is in the holdings of the Naturhistorisches Museum Basel and came to Basel via collection, Coll. Boissier and Bohny. This lot collected by Rugel had the locality of Spring Garden Lake, Florida and led to our sampling there for topotypic material. Further, that some of the syntype material was dispersed on exchange by H. Cuming after the publication of the species description by Pfeiffer has not been established by research.

The shell of $S$. effusa was first illustrated by Pfeiffer (1855: pl. 4 figs 18-20), evidently based on the NHMUK syntypes. Binney (1859: pl. 80 fig. 12; 1878: 429, text-fig. 306; 1885: 442, text-fig. 487) also described and illustrated the shell, which on account of the lots catalogued by Binney (1878: 498, NMNH 39780 and 39781) and Gratacap (1901: 402, AMNH 2135) was based not on type material but on other collections from eastern Florida and can be treated as topotypes. From this material, Binney (1878) described the jaw (p. 429), and described and figured the radula (p. 429 pl. 10 fig. n).

Pilsbry (1948) evidently did not examine the syntypes of $S$. effusa. He dissected specimens from Kissimmee River, Polk County, Florida, for which the reproduction tract was briefly described and fully illustrated (Pilsbry 1948: 790, fig. 421a). The male genitalia were illustrated for further specimens from Bird Island, Florida (Pilsbry 1948: fig. 422b). Based on the presence of an appendix opening to the proximal penis in these specimens, Pilsbry (1948) reassigned S. effusa to Oxyloma. Other specimens from across Florida state, and from North Carolina and New Jersey, evidently only available as dry shells, were similarly identified as $O$. effusum.

In comparing $O$. effusum with $O$. salleanum, Pilsbry (1948: 789) stated "The posterior part of the last whorl is more convex ..., and the aperture is more ample." Pilsbry (1948: 792-793) remarked on the conchological and male genital similarity between $O$. salleanum and $O$. effusum but suggested in respect to the shell "the spire is slightly longer in salleana". Pilsbry (1948) did not formalize the synonymy.

Our observations of the reproductive anatomy of $O$. salleanum and $O$. effusum from the respective type localities largely concur with that of Pilsbry (1948). However, contrary to Pilsbry, in our specimens, on opening the penial sheath the epiphallus was found to be generally strongly convoluted, while the penis more or less straight.

The establishment of Oxyloma effusum as a junior synonym of $O$. salleanum in this study is based on conchology, anatomy, and DNA. Populations from different parts of the range vary in conchological features that have been considered taxonomically important. For example, populations from the type locality of $O$. salleanum have a smaller aperture and consequently taller spire than those from the type locality of $O$. effusum (Fig. 4, morphometric figure). Individuals from the type locality of $O$. salleanum consistently had a large bursa copulatrix sac, while those from eastern Florida (type locality of $O$. effusum) possessed a distinctly smaller bursa copulatrix sac. Other anatomical features showed a similar range of variability across populations. We have not evaluated the status of Succinea salleana var. cordovana Von Martens, 1898.

Oxyloma salleanum populations appear widespread in North America (Fig. 1) but the details of the distribution remain uncertain due to difficulty with identification purely on shell specimens (e.g., most museum material). Using DNA, our study confirmed the species as present in Louisiana, Florida, Virginia, Washington D.C., Wyoming, and Alberta.

In addition to Louisiana, Pilsbry (1948) records O. salleanum from Tennessee, Missouri and Illinois, but all except that from New Orleans, Louisiana were evidently based on dry shell material. To this, we 
can add Pilsbry's (1948) recorded occurrences as O. effusum in Florida, New Jersey and North Carolina, although again only the records from Kissimmee, central Florida were evidently based on dissected animals. Pilsbry (1948) provides no comparative remarks as to how $O$. salleanum and O. effusum were distinguished from other species of Oxyloma recorded from Eastern USA.

Franzen (1966) considered O. salleanum a species of the lower Mississippi River valley, based on dissected animal material from Illinois and Louisiana. Franzen (1966) compared aspects of the shell morphology and anatomy of $O$. salleanum only with $O$. retusa and $O$. haydeni, based on earlier published works (Franzen 1963, 1964).

\section{Discussion}

In this study, we set out to use a suite of tools to delineate species of ambersnails in Oxyloma and as an initial report, we propose the synonomy of $O$. effusum with $O$. salleanum. Phylogenetic analysis of mitochondrial and nuclear genes, and subsequent species delimitation analyses, agree that topotypic individuals representing these nomen form a single clade, with population-level structure. The greatest sequence identity among these populations (0.99-0.95) was similar to that observed in a thorough study (Culver et al. 2013) of another species of Oxyloma (0.93-0.99), within the range expected at the species-level in close relatives. Shell morphometric analysis can distinguish shells from the type localities, however, there is overlap in shell shape. Anatomical characteristics do not distinguish among individuals sampled from the type localities of $O$. salleanum and $O$. effusum but identified characteristics that strongly indicate they are conspecific. The accumulation of evidence from DNA, shell morphometrics, and anatomy indicate that $O$. salleanum and $O$. effusum are a single species. This result aligns with other recent integrative studies of ambersnails that find populationlevel genetic structure similar to that of terrestrial organisms and fewer valid species than existing names.

\section{Are shells useful to distinguish species of Oxyloma?}

Not at the moment. Our study agrees with the two other recent integrative taxonomic studies of succineids (Culver et al. 2013; Vidigal et al. 2018), that shell variability is high and does not align with DNA or anatomical data. Oxyloma salleanum and $O$. effusum are very similar in shape, visible as overlapping convex hulls on Fig. 4. This means that even when only considering similarly-sized specimens from only the type localities, a proportion of each species' individuals are the same shape as the other nominal species. Adult shells from populations present at the type localities are distinguishable by geometric morphometrics, however, distinction at the species level is not supported by the DNA or anatomical data and would align with an interpretation of this distinction as population-specific shapes. Juveniles and individuals from anywhere else in their range are not readily identifiable by shell. We conclude that in this example, some individuals from each population can be distinguished, but species cannot reliably be distinguished by the typical characters in use. We conclude that the nominal form $O$. effusum is an $O$. salleanum with a slightly wider aperture, that feature being typical of the Spring Garden Lake population. It has been suggested that over the lifespan of an Oxyloma, growth transitions across shell forms may confound species identifications, but this was not tested here as we limited our morphometric sample to the largest adult individuals we could find to minimize the variability encountered due to developmental stage. The position of syntype individuals near the representatives from the type localities seems to confirm the identification of representatives of each species being considered. The figure of $O$. salleanum appears to accurately represent the shape of that species, however, the drawing of O. effusum appears to be less representative, a feature that is apparent when examining the drawing as it is somewhat inaccurately rendered in two dimensions. 


\section{Is anatomy useful to distinguish species of Oxyloma?}

The primary criteria for distinguishing species of Oxyloma has been the relative degrees of folding or coiling of the epiphallus and penis within the penial sheath; and the size and shape of the penial appendix. However, these characters vary only subtly and the ontogenetic, inter-population and preservation-induced variations have been poorly studied. In the material of $O$. salleanum (and its synonym $O$. effusum) dissected in this study, and that examined by Franzen (1966), the epiphallus is much more convoluted within the penial sheath than described and illustrated by Pilsbry (1948). This would suggest either natural variation or artefactual effects of preservation in spirit, but in any case, would caution against using this character in species level diagnoses without more clarification of the nature and drivers of variation. The size and shape of the penial appendix likely vary with both animal maturity and preservation in spirit and thus too should be used as a specific diagnostic character with caution until sources of variation are more fully understood. The appendix everts, along with the penis, during mating; such eversion is evident in some dissected specimens (see also illustrations by Quick 1933 regarding European Oxyloma pfeifferi (Rossmässler, 1835) and O. elegans (Risso, 1826)). It is not unreasonable to expect changes in appendix shape and length in the initial changes in eversion, both in natural mating and caused by preservation in alcohol. Nonetheless, as noted by Franzen (1966), the noneverted penial appendix in $O$. salleanum among individuals tends to be uniform in diameter in its entire length, and the apex bluntly rounded. However, the specific diagnostic value of the penial appendix is unclear in the absence of an adequately large geographic sample for $O$. sallaneum and other species of Oxyloma. Perhaps the diagnostic value of the penial appendix will be elucidated by careful studies of Oxyloma mating anatomies.

Most of the specimens of $O$. salleanum examined by dissection in the present study displayed a distinct vergic papillum protruding into the proximal part of the penial chamber. While well known in many land snail taxa, such a structure has not frequently been described in Succineidae. Typically, in succineids the opening of the epiphallus into the penis is a simple orifice without any papilla (Quick 1933; G.M. Barker pers. obs.). However, there have been few published studies that have examined the interior of the penis in Succineidae, despite the potentially high information content in respect to the functional surfaces involved in mate recognition, successful copulation, and successful exchange of seminal material during mating. The distinct vergic papillum in material examined in the present study likely reflects a preservation artifact as live animals were placed directly into $95 \%$ ethanol to preserve DNA for molecular studies. Sudden exposure to ethanol likely led to contraction of the muscles in the genitalia and invoked partial eversion of the male organ that anatomically simulated the onset of penial eversion typically seen in mating succineids.

We have to date been unable to fully evaluate the anatomical distinctiveness of $O$. salleanum relative to other nominal Oxyloma described from the eastern USA, in particular O. retusum (Lea, 1834) which has been considered widely distributed and overlapping in range with $O$. salleanum. The situation is complicated by the fact that many authors publishing on $O$. retusum had examined neither the type material nor topotypic material and thus conspecificity with Succinea retusa Lea, 1834 s. str. remains ambiguous, as does the correct generic placement. Pilsbry (1948) assigned O. retusum to Oxyloma, but on the basis of topotypes of Succinea higginsi Tryon, 1866 from Put-in-Bay, Lake Erie, Ohio which were considered a junior synonym of $O$. retusum. In the present study we sampled for $O$. retusum at Shawnee Lookout, Hamilton County, Ohio near the species' type locality (near Cincinnati, Ohio) but the collected specimens proved in anatomical studies to be allied to Catinella. These are included in trees shown in Supp. file 2, Supp. file 3 to inform future work (terminals labelled "Succineidae sp. Ohio USA").

In conclusion, our study illustrates some of the challenges for taxonomic work with ambersnails. While broadly conservative, these animals exhibit high levels of subtle variation in shells and internal anatomy, making attempts to delineate species challenging. What is more, members of different species and genera 
can co-occur at regional, local, and site scales. Collection of snails matching the original descriptions from the type locality is crucial to any taxonomic work in this group, but importantly all topotypic individuals should be critically evaluated as more than one species (and even genera) can co-occur at a site and not be easily distinguished on shell morphology. Examination of specimens from the region, rather than the type locality, has caused significant past confusion. Shell-only collections from other sites cannot currently be used to understand the range of a species. The next major challenge is to extend this work to the other North American succineids and determine which names represent biologically meaningful units. This work will then hopefully allow identification of useful shell characteristics for species-level distinction, as DNA identification is not as useful for ecologists or natural resource managers presently without ready access to this technique.

\section{Acknowledgments}

We thank the U.S. National Park Service for funding this work. Diane Pavek, National Capital Region, U.S. National Park Service, for facilitating task agreements. Eli Ruiz for collection assistance. Russell Minton for geomorph-wielding. UTRGV Department of Biology and College of Sciences for support of KEP and MMC. Curators: Paul Callomon, Jochen Gerber, Eike Neubert, Jonathan Ablett, Ambros Haenggi. Museums: Carnegie Museum of Natural History, Academy of Natural Sciences of Philadelphia at Drexel University, Field Museum of Natural History, Naturhistorisches Museum der Burgergemeinde Bern, Natural History Museum, London, and Naturhistorisches Museum Basel.

\section{References}

Adams D.C., Collyer M.L. \& Kaliontzopoulou A. 2018. Geomorph: software for geometric morphometric analyses. R package version 3.0.6. Available from https://cran.r-project.org/package=geomorph [accessed 19 May 2019].

Binney W.G. 1859. The terrestrial air-breathing mollusks of the United States and the adjacent territories of North America. Vol. IV. The Boston Journal of Natural History 7: 1-207. https://doi.org/10.5962/bhl.title.6077

Binney W.G. 1878. The terrestrial air-breathing mollusks of the United States and the adjacent territories of North America. Vol. V. Bulletin of the Museum of Comparative Zoology at Harvard College 4: 1-439. https://doi.org/10.5962/bhl.title.6077

Binney W.G. 1885. A manual of American land shells. United States National Museum, Bulletin 28: 1-528. https://doi.org/10.5479/si.03629236.28.1

Binney W.G. \& Bland T. 1869. Land and freshwater shells of North America. Part I. Pulmonata Geophila. Smithsonian Miscellaneous Collections 194: 1-316.

Burch J.B., Patterson C.M. \& Natarajan R. 1966. Chromosomes of four species of North America Succineidae. Venus, Japanese Journal of Malacology 24: 342-353.

Culver M., Herrmann H.-W., Miller M., Roth B. \& Sorenson J. 2013. Anatomical and genetic variation of western Oxyloma (Pulmonata: Succineidae) concerning the endangered Kanab ambersnail (Oxyloma haydeni kanabense) in Arizona and Utah. Scientific Investigations Report, vii. Reston, VA.

https://doi.org/10.3133/sir20135164

Edgar R.C. 2004. MUSCLE: multiple sequence alignment with high accuracy and high throughput. Nucleic Acids Research 32: 1792-1797. https://doi.org/10.1093/nar/gkh340

Folmer O.M., Black W., Hoeh R., Lutz R. \& Vrijenhoek R. 1994. DNA primers for amplification of mitochondrial cytochrome $c$ oxidase subunit I from diverse metazoan invertebrates. Molecular Marine 
Biology and Biotechnology 3: 294-299. Available from https://pubmed.ncbi.nlm.nih.gov/7881515/ [accessed 26 May 2021].

Franzen D.S. 1963. Variations in the anatomy of the succineid gastropod Oxyloma retusa. The Nautilus 76: 82-95. Available from https://www.biodiversitylibrary.org/item/34841\#page/102/mode/1up [accessed 26 May 2021].

Franzen D.S. 1964. Anatomy of the succineid gastropod Oxyloma haydeni. The Nautilus 77: 73-81.

Franzen D.S. 1966. Anatomy of the succineid gastropod Oxyloma salleana (Pfeiffer). The Nautilus 80: $59-69$.

Franzen D.S. 1971. Anatomy and geographic distribution of the succineid gastropod, Succinea vaginacontorta Lea. The Nautilus 84: 131-142.

Franzen D.S. 1983. A new species of Catinella (Succineidae): Pulmonata from southern Michigan. The Nautilus 97: 138-144. https://doi.org/10.5962/bhl.part.5284

Franzen D.S. 1985. Succinea vaginacontorta Lee (Gastropoda: Pulmonata: Succineidae). The Nautilus 99: 94-97. https://doi.org/10.5962/bhl.part.2792

Gratacap L.P. 1901. Catalogue of the Binney and Bland Collection of the terrestrial air-breathing mollusks of the United States and Territories, in the American Museum of Natural History, with enumeration of the types and figured specimens, and supplementary notes. Bulletin of the American Museum of Natural History 14: 335-403. Available from https://digitallibrary.amnh.org/handle/2246/1226 [accessed 26 May 2021].

Hammer Ø., Harper D.A.T. \& Ryan P.D. 2001. PAST: paleontological statistics software package for education and data analysis. Palaeontologia Electronica 4: 1-9. Available from https://palaeo-electronica.org/2001_1/past/issue1_01.htm [accessed 26 May 2021].

Hoang D.T., Chernomor O., von Haeseler A., Minh B.Q. \& Vinh L.S. 2018. UFBoot2: improving the ultrafast bootstrap approximation. Molecular Biology and Evolution 35: 518-522.

https://doi.org/10.1093/molbev/msx281

Huson D.H. \& Scornavacca C. 2012. Dendroscope 3: an interactive tool for rooted phylogenetic trees and networks. Systematic Biology 61: 1061-1067. https://doi.org/10.1093/sysbio/sys062

Kapli P., Lutteropp S., Zhang J., Kobert K., Pavlidis P., Stamatakis A. \& Flouri T. 2017. Multi-rate Poisson tree processes for single-locus species delimitation under maximum likelihood and Markov chain Monte Carlo. Bioinformatics 33: 1630-1638. https://doi.org/10.1093/bioinformatics/btx025

Kearse M., Moir R., Wilson A., Stones-Havas S., Cheung M. \& Sturrock S. 2012. Geneious basic: an integrated and extendable desktop software platform for the organization and analysis of sequence data. Bioinformatics 28: 1647-1649. https://doi.org/10.1093/bioinformatics/bts199

Li W., Cowley A., Uludag M., Gur T., McWilliam H., Squizzato S., Park Y.M., Buso N. \& Lopez R. 2015. The EMBL-EBI bioinformatics web and programmatic tools framework. Nucleic Acids Research 43: W580-W584. https://doi.org/10.1093/nar/gkv279

Masters B.C., Fan V. \& Ross H.A. 2011. Species delimitation - a geneious plugin for the exploration of species boundaries. Molecular Ecology Resources 11: 154-157.

https://doi.org/10.1111/j.1755-0998.2010.02896.x

Miles C.D. 1958. The family Succineidae (Gastropoda: Pulmonata) in Kansas. University of Kansas Science Bulletin 38: 1499-1543.

Minh B.Q., Nguyen M.A.T. \& von Haeseler A. 2013. Ultrafast approximation for phylogenetic bootstrap. Molecular Biology and Evolution 30: 1188-1195. https://doi.org/10.1093/molbev/mst024 
Nekola J.C. 2014. Overview of the North American terrestrial gastropod fauna. American Malacological Bulletin 32: 225-235. https://doi.org/10.4003/006.032.0203

Nguyen L.-T., Schmidt H.A., von Haeseler A. \& Minh B.Q. 2015. IQ-TREE: a fast and effective stochastic algorithm for estimating maximum-likelihood phylogenies. Molecular Biology and Evolution 32: 268-274. https://doi.org/10.1093/molbev/msu300

Örstan A. 2010. Reproductive biology and annual population cycle of Oxyloma retusum (Pulmonata: Succineidae). American Malacological Bulletin 28: 113-120.

https://doi.org/10.4003/006.028.0203

Patterson C.M. 1971. Taxonomic studies on the land snail family Succineidae. Malacological Review 4: $131-202$.

Patterson C.M. 1972. Generic and specific characters in the land snail family Succineidae. Malacological Review 6: 54-56.

Patterson C.M. 1973. Parallel evolution of shell characters in succineids inhabiting waterfalls. Bulletin of the American Malacological Union 38: 28.

Pfeiffer L. 1850. Descriptions of twelve new species of Vitrina and Succinea, from the collection of H. Cuming, Esq. Proceedings of the Zoological Society of London 17 (1849): 132-134. Available from https://www.biodiversitylibrary.org/page/30572567 [accessed 1 Jun. 2021].

Pfeiffer L. 1853. Monographia Heliceorum Viventium. Sistens Descriptiones Systematicas et Criticas omnium huius Familiae Generum et Specierum hodie Cognitarum, Vol. 3. F.A. Brockhaus, Leipzig. https://doi.org/10.5962/bhl.title.10791

Pfeiffer L. 1855. Descriptions of fifty-seven new species of Helicea, from Mr. Cuming's collection. Proceedings of the Zoological Society of London 1854: 286-298. https://doi.org/10.1111/j.1469-7998.1854.tb07277.x

Pilsbry H.A. 1948. Land Mollusca of North America (North of Mexico). Vol. 2, Part 2. Academy of Natural Sciences of Philadelphia, Philadelphia, PA.

Puillandre N., Lambert A., Brouillet S. \& Achaz G. 2011. ABGD, Automatic Barcode Gap Discovery for primary species delimitation. Molecular Ecology 21: 1864-1877.

https://doi.org/10.1111/j.1365-294X.2011.05239.x

Quick H.E. 1933. The anatomy of British Succinneae. Proceedings of the Malacological Society of London 20: 295-318.

R Core Team. 2017. R: A Language and Environment for Statistical Computing. R Foundation for Statistical Computing, Vienna.

Reeve L., Brooks V., Reeve F., Sowerby G.B., Sowerby G.B., Taylor J.E., Reeve B., Reeve, Savill E., Co, Spottiswoode, Co, Vincent Brooks D. \& Son. 1873. Conchologia Iconica, or, Illustrations of the Shells of Molluscous Animals, Vol. 18. Reeve, Brothers, London.

https://doi.org/10.5962/bhl.title.8129

Rohlf F.J. 1993. Relative warp analysis and an example of its application to mosquito wings. In: Marcus L.F., Bello E. \& García-Valdecasas A. (eds) Contributions to Morphometrics: 131-159. Museo Nacional de Ciencias Naturales-CSIC, Madrid.

Rohlf F.J. 2001. TpsDig. Available from http://www.sbmorphometrics.org/ [accessed 15 Apr. 2020].

Rohlf F.J. 2003. TpsRelw, relative warps analysis. Available from http://www.sbmorphometrics.org/ [accessed 15 Apr. 2020]. 
PEREZ K.E. et al., Taxonomy of North American species of Oxyloma

Rohlf F.J. 2006. Tpsutil. Available from http://www.sbmorphometrics.org/ [accessed 15 Apr. 2020].

Roth B., Jadin R. \& Robert G. 2013. The taxonomic status of Deroceras hesperium Pilsbry, 1944 (Gastropoda: Pulmonata: Agriolimacidae), a species of conservation concern in Oregon, USA. Zootaxa 3691: 453-460. https://doi.org/10.11646/zootaxa.3691.4.4

Saghai-Maroof M.A., Soliman K.M., Jorgensen R.A. \& Allard R.W. 1984. Ribosomal DNA spacerlength variation in barley: Mendelian inheritance, chromosomal location and population dynamics. Proceedings of the National Academy of Sciences of the United States of America 81: 8018-8021. https://doi.org/10.1073/pnas.81.24.8014

Steury B.W. \& Pearce T.A. 2014. Land snails and slugs (Gastropoda: Caenogastropoda and Pulmonata) of two national parks along the Potomac River near Washington, District of Columbia. Banisteria 43: $3-20$.

USGS [United States Geological Survey]. 2004. North America Rivers and Lakes. Available from https://www.sciencebase.gov/catalog/item/4fb55df0e4b04cb937751e02 [accessed 15 May 2020].

Vidigal T.H.D.A., Coscarelli D., Paixão H., Bernardes S., Montresor L.C. \& Pepato A.R. 2018. Integrative taxonomy of the neotropical genus Omalonyx (Elasmognatha: Succineidae). Zoologica Scripta 47: 174-186. https://doi.org/10.1111/zsc.12271

Wade C.M., Mordan P.B. \& Clarke B. 2001. A phylogeny of the land snails (Gastropoda: Pulmonata). Proceedings of the Royal Society of London B 268: 413-422. https://doi.org/10.1098/rspb.2000.1372

Weber G.W. \& Bookstein F.L. 2011. Virtual Anthropology: A Guide to a New Interdisciplinary Field. Springer-Verlag, Wien, London.

Westerlund C.A. 1885. Fauna der in der Paläarctischen Region (Europa, Kaukasien, Sibirien, Turan, Persien, Kurdistan, Armenien, Mesopotamien, Kleinasien, Syrien, Arabien, Egypten, Tripolis, Tunesien, Algerien und Marocco) lebenden Binnenconchylien. Vol. V. Fam. Succineidae, Auriculidae, Limnaeidae, Cyclostomidae und Hydrocenidae. H. Ohlsson, Lund.

Wu S.K. 1993. Notes on the succineid land snails of New Mexico. Malacological Review 26: 91-94.

Manuscript received: 21 May 2020

Manuscript accepted: 4 March 2021

Published on: 1 July 2021

Topic editor: Rudy Jocqué

Section editor: Thierry Backeljau

Desk editor: Pepe Fernández

Printed versions of all papers are also deposited in the libraries of the institutes that are members of the EJT consortium: Muséum national d'histoire naturelle, Paris, France; Meise Botanic Garden, Belgium; Royal Museum for Central Africa, Tervuren, Belgium; Royal Belgian Institute of Natural Sciences, Brussels, Belgium; Natural History Museum of Denmark, Copenhagen, Denmark; Naturalis Biodiversity Center, Leiden, the Netherlands; Museo Nacional de Ciencias Naturales-CSIC, Madrid, Spain; Real Jardín Botánico de Madrid CSIC, Spain; Zoological Research Museum Alexander Koenig, Bonn, Germany; National Museum, Prague, Czech Republic. 
Supp. file 1: List of specimens used in our study, including their original sampling localities. Localities marked with asterisks $(*)$ denote type localities. Alphanumeric identifiers correspond to GenBank accession numbers. \# indicates specimens used in morphometric analysis. ${ }^{\wedge}$ indicates types.

https://doi.org/10.5852/ejt.2021.757.1419.4567

Supp. file 2: Maximum likelihood phylogeny from 142 COI sequences. Ultrafast bootstrap support indicated behind nodes. Clades supported by species delimitation analyses indicated with a filled circle. Type localities indicated with an *. Individuals from the type locality of $O$. effusum (L. Pfeiffer, 1853) colored red and $O$. salleanum (L. Pfeiffer, 1850) colored green.

https://doi.org/10.5852/ejt.2021.757.1419.4569

Supp. file 3: Maximum likelihood phylogeny from 51 LSU sequences. Ultrafast bootstrap support indicated behind nodes. Type localities indicated with an *. Individuals from the type locality of O. effusum (L. Pfeiffer, 1853) colored red and O. salleanum (L. Pfeiffer, 1850) colored green.

https://doi.org/10.5852/ejt.2021.757.1419.4571 